\title{
The relationship between calcium and obesity
}

\author{
Çayan Kuytak@i), Jale Çatak@ \\ Department of Nutrition and Dietetics, Istanbul Sabahattin Zaim University, Faculty of Health Sciences, Istanbul, Turkey
}

\begin{abstract}
Dietary and behavioral approaches to obesity, a serious public health problem worldwide, have not prevented the progression of obesity. Scientists have explored the mechanisms of adipose tissue and intracellular calcium to find different therapeutic methods for obesity. Although the first step in the treatment of obesity is energy restriction, studies have shown that dietary calcium can play an important role not only in the regulation of skeletal integrity but also in energy metabolism. The anti-obesity effect of calcium has been demonstrated by animal studies, observational population studies and randomized clinical studies. However, some studies have failed to explain the effect of calcium in obesity treatment. Although the protective effects of calcium against obesity and comorbidities are promising, larger studies are needed. This review investigates the anti-obesity mechanisms of action of dietary calcium in animal studies, observational population studies, and randomized clinical trials.

Keywords: Calcium metabolism, calcium, obesity.
\end{abstract}

Obesity is defined as excessive fat accumulation that may be harmful to health. ${ }^{[1]}$ Economic growth, industrialization, ease of transportation, urbanization, sedentary lifestyle, processed foods, and transition to diets with high energy intake, in many countries, the prevalence of obesity has doubled, or even quadrupled..$^{[2]}$ Obesity greatly increases the risk of chronic diseases such as type 2 diabetes, cardiovascular diseases, certain cancers, depression and injuries, which lead to mortality and morbidity. ${ }^{[2,3]}$

Today, dietary and behavioral approaches regarding obesity, which is a serious public health problem worldwide, have been unable to prevent the progression of obesity. ${ }^{[4]}$ The scientific community has investigated the mechanisms that effect adipose tissue in order to discover different therapeutic methods for obesity. ${ }^{[4,5]}$

Mechanisms of the underlying pathophysiology of obesity and comorbid diseases may be factors related to intracellular and extracellular calcium. ${ }^{[6]}$ Calcium is the most abundant micronutrient in the human body. ${ }^{[6]}$ Calcium plays a role in many biological functions, especially in skeletal mineralization, as well as in muscle contraction and cell division in glycogen metabolism. ${ }^{[7]}$ Calcium metabolism in the human body can be controlled by negative feedback mechanisms such as intestinal absorption, renal reabsorption, and bone storage. ${ }^{[8]}$ Various hypotheses have been proposed regarding the metabolic effect of calcium on adipose tissue in the treatment of obesity. ${ }^{[9]}$

\section{STUDIES SUPPORTING CALCIUM ASSOCIATION IN OBESITY}

The effect of calcium on body weight and body fat distribution has been confirmed by recent studies. ${ }^{[10]}$ The relationship between body weight and calcium intake was first reported by McCarron ${ }^{[11]}$ While the purpose of their study was to investigate the relationship between nutrients and blood pressure, the increased calcium intake with food was found to have a negative correlation

Received: August 21, 2019 Accepted: September 10, 2019 Published online: April 15, 2020

Correspondence: Çayan Kuytak. İstanbul Sabahattin Zaim Üniversitesi, Sağlık Bilimleri Fakültesi, Beslenme ve Diyetetik Bölümü, 34303 Küçükçekmece, İstanbul, Türkiye. Tel: +90 536 - 8530564 e-mail: cayankuytak@hotmail.com 
with body weight. Zemel et al. ${ }^{[12]}$ examined triglyceride accumulation and lipolysis activity of adipose tissue in low and high calcium intake in mouse models, and as a result, found that there was an inverse correlation between calcium intake and adipose tissue accumulation. In the NHANES III study of over 7,000 men and women, low calcium intake was associated with fat mass. ${ }^{[13]}$ Another study of 283 participants between the ages of 18-64 reported that low calcium intake was a risk factor for being overweight and obesity. ${ }^{[14]}$

A cross-sectional epidemiological study of 1,259 participants conducted in Poland reported there was a negative correlation between dietary calcium and body mass index (BMI). ${ }^{[15]}$ Suhett et al. ${ }^{[16]}$ conducted a study on 350 eight and nine-yearold children found that children with low calcium intake had increased waist circumference and reported that low calcium intake was associated with abdominal obesity. Another study indicated that people who take less than $600 \mathrm{mg}$ of calcium per day with nutrients had BMI in the category of $>25 \mathrm{~kg} / \mathrm{m}^{2} \cdot{ }^{[17]}$

Lu et al. ${ }^{[18]}$ observed children and adolescent for a period of three years, and divided them into two groups according to high and low dairy intake, in which $38 \%$ of the low dairy intake group were found overweight and this finding was related to calcium's potential effect on weight control. One study found that calcium intake increased fat oxidation in participants who lost weight. ${ }^{[19]}$

Despite these studies, other studies reported there was no clear relationship between calcium intake and body weight. ${ }^{[10-12]}$ One two-year study found that overweight and obese individuals had no significant difference in body weight after daily $1,500 \mathrm{mg}$ calcium supplementation. ${ }^{[10]}$ Another study assigned obese and overweight women into two groups, the placebo group and the group receiving $500 \mathrm{mg}$ daily calcium supplement; despite restrictions on energy intake, there was no significant difference in weight change between the groups. ${ }^{[20]}$

In a study by Jones et al., ${ }^{[21]} 49$ people received diets containing 700-1,400 mg calcium for 12 weeks; at the end of this study, although participants were given a calcium-rich diet and a diet restricted in energy intake, it was reported that calcium did not impact weight loss. One study on 2,267 people examined the relationship between calcium intake via dairy consumption and body weight and waist circumference; at the end of this six-year study, the relationship between calcium intake through dairy products and anthropometric changes could not be explained. ${ }^{[22]}$

One randomized controlled study examined the body weights of 323 healthy males who received calcium supplements for two years and reported that calcium supplements did not have significant effect on body composition. ${ }^{[23]}$ In a cross-sectional study conducted on 236 healthy female students between the ages of 18-30 selected randomly among the students of Isfahan University of Medical Sciences, no significant relationship was found between calcium intake and excess weight and obesity. ${ }^{[24]}$ Larsen et al. ${ }^{[25]}$ reported in a study that there was a weak relationship between dietary calcium loss and weight loss.

\section{PROPOSED MECHANISMS IN CALCIUM-OBESITY RELATIONSHIP}

Various mechanisms have been proposed to explain the effects observed in studies on the effect of calcium intake on obesity. ${ }^{[11]}$ One anti-obesity action mechanism of calcium is related to the amount of intracellular $\mathrm{Ca}^{2+}$ in the adipocyte cell. This mechanism is regulated by 1,25-dihydroxyvitamin $\mathrm{D} \quad\left(1.25-(\mathrm{OH})_{2}-\mathrm{D}\right)$ which plays a role in inducing lipogenesis and stimulating intracellular $\mathrm{Ca}^{2+}$ in the adipocyte, leading to lipolysis. ${ }^{[26,27]}$ In high calcium diet, while 1,25-dihydroxyvitamin $\mathrm{D}\left(1.25-(\mathrm{OH})_{2}-\mathrm{D}\right)$ is suppressed, concentration of intracellular $\mathrm{Ca}^{2+}$ in adipose tissue decreases, which results in increased lipolytic activity and reduced lipogenesis, explaining the fat loss model in adipose tissue. This process has been used to explain the antiobesity effect. ${ }^{[9]}$

In recent years, studies have reported that the activity of the calcium sensitive receptor may play a role in the modulation of adipocyte cell function. ${ }^{[27]}$ Increase in intracellular calcium in the adipocyte cell following low calcium intake is explained as follows: according to this model, activation of calcium-sensitive receptors found in adipose tissue results in increased vitamin $\mathrm{D}$ in circulation. This can be attributed to the potential effect of greater activation of lipogenic markers as well as decreased activation of lipolytic enzymes (Figure 1). ${ }^{[28]}$ 


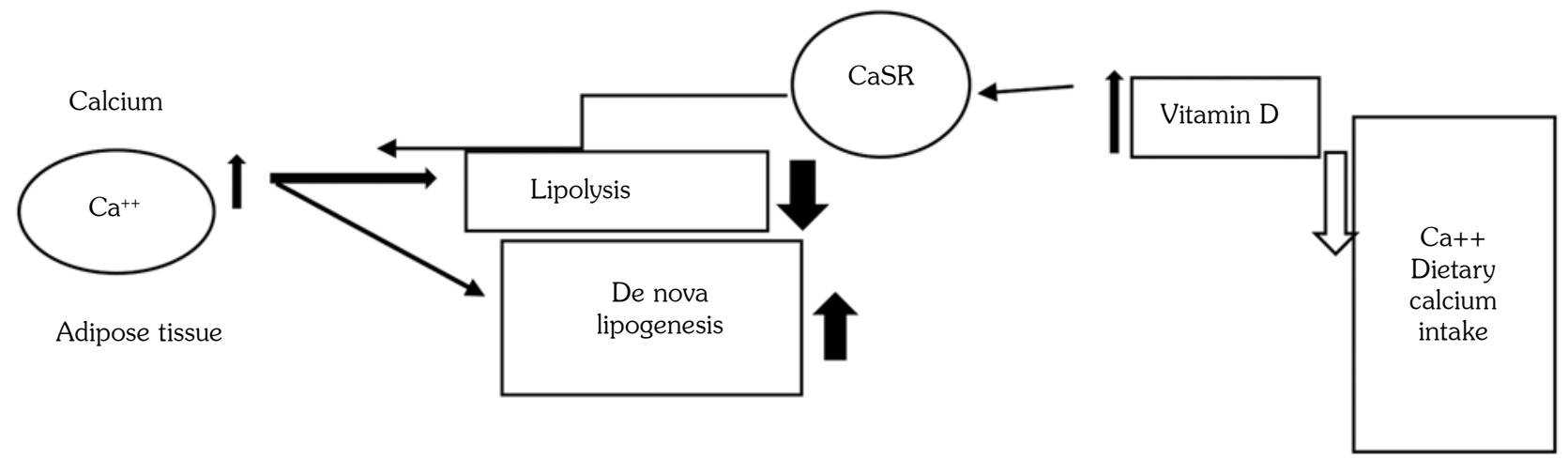

Figure 1. Model showing the role of increased intracellular calcium in fat synthesis within adipose tissue, during low calcium intake. . $^{[2]}$

Ca: Calcium; CaSR: Calcium sensitive receptor.

Another mechanism that may allow calcium to decrease body weight is by decreasing intestinal fat absorption and increasing fecal fat excretion. Calcium forms insoluble calcium soaps with fatty acids in the intestinal tract, therefore increasing the amount of fecal fat removal, with the potential effect of regulating body weight. ${ }^{[29]}$

One meta-analysis compared $1,241 \mathrm{mg}$ daily calcium intake to low-calcium intake (<700 mg) and reported $5 \mathrm{~g} /$ day increase in fecal fat levels with high calcium intake. ${ }^{[30]}$ Another study demonstrated a positive correlation between increased calcium intake and fecal fat amount. ${ }^{[31]}$ In the period following the increase of calcium intake from $500 \mathrm{mg} /$ day to $1,800 \mathrm{mg} /$ day, $8.2 \mathrm{~g}$ increase in fecal fat loss was detected. ${ }^{[32]} \mathrm{In}$ a similar study, total fecal fat excretion doubled by increasing calcium intake by $1,600 \mathrm{mg}$ for seven days (Figure 2). ${ }^{[29]}$
In a randomized controlled study by Soerensen et al., ${ }^{[33]} 15$ young male subjects were administered $500 \mathrm{mg}$ calcium without dairy products as a control diet, $1,700 \mathrm{mg}$ calcium based on milk, and $1,700 \mathrm{mg}$ calcium based on cheese, respectively. At the end of the study, it was found that those who were on control diet had significantly less amount of fecal fat excretion compared to those with milk or cheese-based diet.

At the same time, animal studies have also shown that calcium affected sense of appetite and it was observed that calcium was an effective micronutrient in regulating appetite. ${ }^{\text {[2] }}$

In conclusion calcium is a micronutrient that has recently gained significance in regulating body weight or body fat distribution. While it is not a silver bullet in the struggle against obesity, it plays a large role despite being a small mineral.

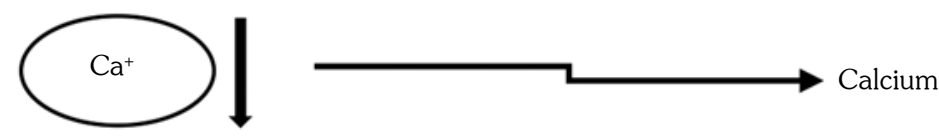

Adipose tissue

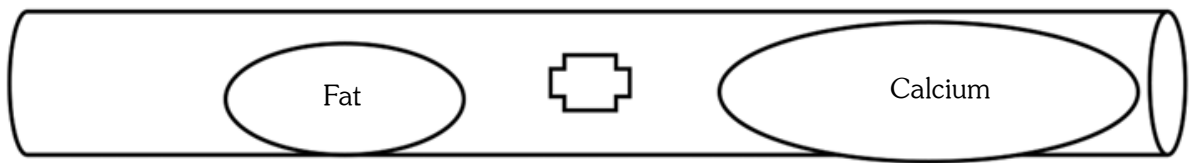

Fecal fat excretion

Intestinal lumen

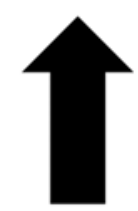

Figure 2. Mechanism showing increase in fecal fat excretion with decreased intracellular calcium in adipose tissue of within the intestinal system. ${ }^{[29]}$

Ca: Calcium. 
The anti-obesity effect of calcium has been demonstrated in animal studies, observational population studies, and randomized clinical trials. However, some studies were unable to explain the effect of calcium in obesity treatment. While the protective effects of calcium against obesity and comorbidities seem promising, there is a need for studies of larger scope.

\section{Declaration of conflicting interests}

The authors declared no conflicts of interest with respect to the authorship and/or publication of this article.

\section{Funding}

The authors received no financial support for the research and/or authorship of this article.

\section{REFERENCES}

1. WHO. Available at: https://www.who.int/topics/ obesity/en/.

2. Hruby A, Hu FB. The epidemiology of obesity: A big picture. Pharmacoeconomics 2015;33:673-89.

3. Chan RS, Woo J. Prevention of overweight and obesity: how effective is the current public health approach. Int J Environ Res Public Health 2010;7:76583.

4. Godin G, Bélanger-Gravel A, Paradis AM, Vohl MC, Pérusse L. A simple method to assess fruit and vegetable intake among obese and non-obese individuals. Can J Public Health 2008;99:494-8.

5. Berry DC, Stenesen D, Zeve D, Graff JM. The developmental origins of adipose tissue. Development 2013;140:3939-49.

6. Bravo-Saqua R, Reyes M, Lavandero S, Cifuentes M. Calcium in obesity and related diseases: the calciumsensing receptor as a novel mediator. In: Collins JF, editor. Molecular, Genetic, and Nutritional Aspects of Major and Trace Minerals. New York: Academic Press; 2017. p. 35-44.

7. Pravina P, Sayaji D, Avinash M. Calcium and its role in human body. Int $\mathrm{J}$ Res Pharm Biomed Sci 2013;4:659-68.

8. Peacock M. Calcium metabolism in health and disease. Clin J Am Soc Nephrol 2010;5:S23-30.

9. Yaldız DN. Kadınlarda Diyette Farklı Miktarlarda Kalsiyum Tüketiminin Ağırlık Kaybı ve Bazı Antropometrik Ölçümler Üzerine Etkisi, [Yüksek Lisans Tezi] Ankara: Başkent Üniversitesi, Sağllk Bilimleri Enstitüsü Beslenme ve Diyetetik Ana Bilim Dali; 2015.

10. Yanovski JA, Parikh SJ, Yanoff LB, Denkinger BI, Calis KA, Reynolds JC, et al. Effects of calcium supplementation on body weight and adiposity in overweight and obese adults: a randomized trial. Ann Intern Med 2009;150:821-9.
11. McCarron DA. Dietary calcium as an antihypertensive agent. Nutr Rev 1984;42:223-5.

12. Zemel MB, Shi H, Greer B, Dirienzo D, Zemel PC. Regulation of adiposity by dietary calcium. FASEB $\mathrm{J}$ 2000;14:1132-8.

13. Gerstner G, de Vrese M. Dietary and supplemental calcium and its role in weight loss: Weighing the evidence. Novel Food Ingredients for Weight Control; 2007. p. 232-62.

14. Major GC, Chaput JP, Ledoux M, St-Pierre S, Anderson GH, Zemel MB, et al. Recent developments in calcium-related obesity research. Obes Rev 2008;9:428-45.

15. Skowronska-Józwiak E, Jaworski M, Lorenc R, Karbownik-Lewinska M, Lewinski A. Low dairy calcium intake is associated with overweight and elevated blood pressure in Polish adults, notably in premenopausal women. Public Health Nutr 2017;20:630-7.

16. Suhett LG, Silveira BKS, Filgueiras MS, Peluzio MDCG, Hermsdorff HHM, Novaes JF. Inverse association of calcium intake with abdominal adiposity and C-reactive protein in Brazilian children. Public Health Nutr 2018;21:1912-20.

17. Demir H, Özkorucuklu Y. Üniversite öğrencilerinde süt ve süt ürünleri tüketimi, kalsiyumun antropometrik ölçümlerle ilişkisi. IGUSABDER 2018;5:494-516.

18. Lu L, Xun P, Wan Y, He K, Cai W. Long-term association between dairy consumption and risk of childhood obesity: a systematic review and metaanalysis of prospective cohort studies. Eur J Clin Nutr 2016;70:414-23.

19. Smilowitz JT, Wiest MM, Teegarden D, Zemel MB, German JB, Van Loan MD. Dietary fat and not calcium supplementation or dairy product consumption is associated with changes in anthropometrics during a randomized, placebo-controlled energy-restriction trial. Nutr Metab (Lond) 2011;8:67.

20. Kabrnová-Hlavatá K, Hainer V, Gojová M, Hlavaty P, Kopsky V, Nedvídková J, et al. Calcium intake and the outcome of short-term weight management. Physiol Res 2008;57:237-45.

21. Jones KW, Eller LK, Parnell JA, Doyle-Baker PK, Edwards AL, Reimer RA. Effect of a dairy- and calcium-rich diet on weight loss and appetite during energy restriction in overweight and obese adults: a randomized trial. Eur J Clin Nutr 2013;67:371-6.

22. Vergnaud AC, Péneau S, Chat-Yung S, Kesse E, Czernichow S, Galan P, et al. Dairy consumption and 6-y changes in body weight and waist circumference in middle-aged French adults. Am $\mathrm{J}$ Clin Nutr 2008;88:1248-55.

23. Reid IR, Ames R, Mason B, Bolland MJ, Bacon CJ, Reid HE, et al. Effects of calcium supplementation on lipids, blood pressure, and body composition in healthy older men: a randomized controlled trial. Am J Clin Nutr 2010;91:131-9. 
24. Sahar Saraf B, Ghanjalı N, Seyyed Ghalaeh R, Azadbakht L. Investigation of the effects of milk products and calcium introduction general and central obesity in Isfahan University Institute of Medical Sciences Iran. Health System Research 2011;7:25-34.

25. Larsen SC, Ängquist L, Ahluwalia TS, Skaaby $\mathrm{T}$, Roswall $\mathrm{N}$, Tjønneland $\mathrm{A}$, et al. Interaction between genetic predisposition to obesity and dietary calcium in relation to subsequent change in body weight and waist circumference. Am J Clin Nutr 2014;99:957-65.

26. Zemel MB. Regulation of adiposity and obesity risk by dietary calcium: mechanisms and implications. J Am Coll Nutr 2002;21:146-51.

27. Cifuentes M, Albala C, Rojas C. Calcium-sensing receptor expression in human adipocytes. Endocrinology 2005;146:2176-9.

28. Villarroel $\mathrm{P}$, Villalobos $\mathrm{E}$, Reyes $\mathrm{M}$, Cifuentes $\mathrm{M}$. Calcium, obesity, and the role of the calcium-sensing receptor. Nutr Rev 2014;72:627-37.
29. Soares MJ, She-Ping-Delfos WL. Postprandial energy metabolism in the regulation of body weight: is there a mechanistic role for dietary calcium? Nutrients 2010;2:586-98.

30. Christensen R, Lorenzen JK, Svith CR, Bartels EM, Melanson EL, Saris WH, et al. Effect of calcium from dairy and dietary supplements on faecal fat excretion: a meta-analysis of randomized controlled trials. Obes Rev 2009;10:475-86.

31. Kjølbæk L, Lorenzen JK, Larsen LH, Astrup A. Calcium intake and the associations with faecal fat and energy excretion, and lipid profile in a free-living population. J Nutr Sci 2017;6:e50.

32. Tremblay A, Gilbert JA. Human obesity: is insufficient calcium/dairy intake part of the problem? J Am Coll Nutr. 2011;30:449-53.

33. Soerensen KV, Thorning TK, Astrup A, Kristensen M, Lorenzen JK. Effect of dairy calcium from cheese and milk on fecal fat excretion, blood lipids, and appetite in young men. Am J Clin Nutr 2014;99:984-91. 